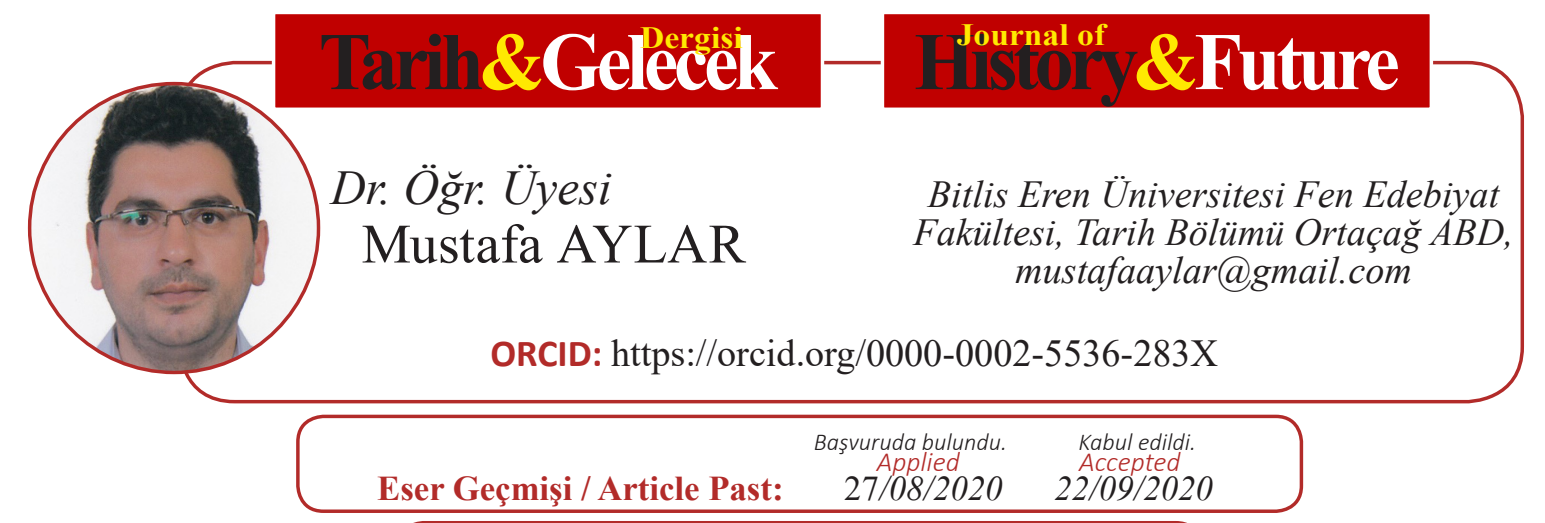

Araştırma Makalesi

DOI: http://dx.doi.org/10.21551/jhf.786565

Research Paper

Orjinal Makale / Orginal Paper

\title{
Abbâsîler'in Kuruluşundan IX. Yüzyılın Sonuna Kadar Rey Şehrinde Siyasi Durum
}

\author{
The Political Situation in the City of Rayy from the Foundation of \\ the Abbasids to the End of the 9th Century
}

\section{$\ddot{O} \mathbf{z}$}

Eski Çağ’larda ismi kaynaklarda Ragha-Raga şeklinde kaydedilen günümüzdeki Tahran'ın 8 km güneydoğunda yer alan Rey şehri, Orta Asya'yı Anadolu'ya bağlayan tarihi İpek yolu üzerinde bulunmasından dolayı önemli bir jeopolitik konuma sahip olmuştur. Birçok İslâm coğrafyacısı tarafından Cibâl Eyaletinin bir şehri sayılan Rey, Hulefâ-yi Râşidîn döneminde İslâm hâkimiyetine geçmiştir. Ancak şehirdeki Arap-İslâm hâkimiyetinin yerleşmesi biraz zaman almış, şehirde zaman zaman isyanlar meydana gelmiştir. Emevî Hilafetinin kurulmasından sonra Rey, Emevî idaresine geçmiş ancak bu dönemde şehirdeki problemler daha da artmıştır. Önceki dönemlerde yaşanan problemlere rağmen Rey, Abbâsî Hilafetinin kurulmasından sonra Abbâsîlerin en önemli şehirlerinden birisi haline gelmiştir. Abbâsîler zamanında şehirde zaman zaman problemler ortaya çıkmasına karşın IX. yüzyılın ortasına kadar Rey’de nispeten istikrarlı bir dönem yaşanmıştır. Fakat bu yüzyılın ikinci yarısından itibaren şehir, mahalli hükümdarlıkların hedefi olmuş ve çatışmaların ortasında kalmıştır.

Bu çalışmada; Abbâsî hilafetinin kuruluşundan IX. yüzyılın sonuna kadar Rey şehrinin siyasi durumu incelenmiştir. $\mathrm{Bu}$ bağlamda bu dönemde Rey şehrinde yaşanan siyasi gelişmeler kronolojik olarak ele alınmıştır. Araştırmada birinci elden Arapça ve Farsça kaynakların yanında konu ile ilgili ikinci kaynaklara müracaat edilmiştir.

Anahtar Kelimeler: Rey, Abbâsîler, IX. yüzyıl.

\section{Abstract}

The city of Rayy, which was recorded as Ragha-Raga in ancient times, is located $8 \mathrm{~km}$ southeast of Tehran today, and has an important geopolitical position due to its location on the historical Silk Road connecting Central Asia to Anatolia. The city of Rayy, is considered as a city of the Jibâl State by many Islamic geographers, passed under Islamic rule during the the Rashidun Caliphs period. However, it took time for the Arab-Islamic rule to settle in the city, and riots took place from time to time in the city. After the establishment of the Umayyad Caliphate, the city passed under the Umayyad administration, but the problems in the city increased during this period. Despite the problems experienced in previous periods, the city of Rayy became one of the most important cities of the Abbasids after the establishment of the Abbasid Caliphate. Although there were occasional problems in the city during the time of the Abbasids, a relatively stable era was experienced in the city of Rayy until the middle of the 9th century. But since the second half of this century, the city has been the target of local rulers and has been caught in the middle of conflicts.

In this study; The political situation of the city of Rayy from the establishment of the Abbasid Caliphate to the end of the 9th century has been studied. In this context, the political developments in Rey city during this period were handled chronologically. In the research, first hand Arabic and Persian sources as well as second sources related to the subject were consulted.

Keywords: Rayy, Abbasids, 9th century.

ATIF: AYLAR Mustafa, "Abbâsîler'in Kuruluşundan IX. Yüzyılın Sonuna Kadar Rey Şehrinde Siyasi Durum", Tarih ve Gelecek Dergisi, 6/3 (Eylül 2020), s. (1025-1037) 


\section{Giriş}

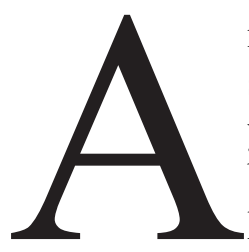

rkeolojik çalışmalarda Rey şehrinin çok eski bir tarihe ve ileri bir medeniyete sahip olduğu ortaya çıkmıştır ve bulunan çömleklerde şehir tarihinin beş bin y1l öncesine kadar gittiği tahmin edilmektedir. ${ }^{1}$ Bunun yanında Eski Çağ'dan beri İpek Yolu'nun kavşak noktasında yer alan Rey, ticari açıdan mühim bir konumdaydı. Rey'in birçok ülkeden gelen tüccarların uğrak yeri olması şehrin ekonomisine büyük katkı sağlamaktaydı. Ticari ehemmiyetinin yanında şehir, dini açıdan da önemli bir konumdaydı ve Eski Çağlar'da Zerdüştîler için mühim bir yere sahipti. Avesta'da Ragha'nın (Rey) Ahura Mazda tarafından yaratılan on ikinci yer olduğu belirtilmesi şehrin Zerdüştîler için kutsal bir yer olarak benimsenmesine yol açmıştı. ${ }^{2}$ Sâsânîler zamanında ise Zerdüştî din adamlarının başı olan baş mûbed Rey'in hâkimi idi. ${ }^{3}$ Öte yandan Rey, çeşitli dönemlerde buraya hâkim olan devletler tarafından ehemmiyetini koruyan bir şehir olmuştur. Şehir, ikliminin uygun olmasından dolayı Part hükümdarları tarafından bahar mevsiminde ikametgâh olarak seçilmişti. Bununla birlikte Ahameniş İmparatorluğunun satraplığının başlıca, Media eyaletinin ana şehirlerinden birisi idi. $^{4}$

Rey, 21 (642) yılında Hz. Ömer döneminde İran fetihlerini müteakiben son Sâsânî hükümdarı III. Yezdicerd'in Nihavend Savaşında yenilgiye uğramasından iki ay sonra Urve b. Zeyd et-Tâî tarafından barış yoluyla ele geçirildi. Fakat şehir halkı İslâm idaresine karşı birkaç defa isyan edince Hz. Osman zamanında Karaza b. Kâ’b komutasında Müslümanlar şehri yeniden fethettiler (23/644). Ancak şehirdeki Arap-İslâm hâkimiyetinin yerleşmesi biraz zaman aldı. ${ }^{5}$

Muaviye zamanında bir dönem Rey valisi Kesîr b. Şihab b. el-Hüseyin idi. ${ }^{6}$ Ancak Emevîler zamanında Rey'in siyasi vaziyeti sıkıntılı bir süreç geçirmiştir. Emevîler döneminde yaşanan iç karışıklıklar nedeniyle muhalif kesimden birçok kişi Rey'e gelmekteydi. ${ }^{7}$ Bu karışıklıklara rağmen şehir önemini koruyordu. Kûfe Valisi Ubeydullah b. Ziyâd, Hz. Hüseyin ile savaşma karşılığında Rey hükümetini Ömer b. Sa'd'a teklif etmiş ve bunun üzerine Ömer b. Sa'd, Rey hükümetini elde etmek için Kerbela'da Hz. Hüseyin ile savaşmaya gitmişti. ${ }^{8}$

64 (683) yılında Halife Yezîd öldüğü zaman Rey şehrinde Ferruhân liderliğinde bir isyan çıktı. 68 (687-88) yılında ise Rey halkı Emevîlere karşı Hariciler’e yardımda bulundular. Bunun

James Darmesteter, The Zend-Avesta, Vendidad (Oxford: Clarendon Press, 1880), 8; V. Minorsky, "Rey”, IA, c. IX (İstanbul, 1964), 721.

3 İgor M. Diakonoff, Tarih-i Mâd, çev. Kerîm Keşâverz (Tahran: Bongâh-i Tercüme ve Neşr-i Kitâb, 1345$), 463$.

4 Hasan Pîrniyâ, Tarih-i İran-i Bâstân, c. III (Tahran: Donya-y1 Kitâb, 1375), 2217, 2644-45.

5 Belâzûrî, Ahmed b. Yahyâ, Fütûhu'l-Büldân (Beyrut: Dâr ve Mektebü'l-Hilâl, 1988), 309, 311; Türkçe trc., Fütûhu'l-Büldân (Ülkelerin Fetihleri), çev. Mustafa Fayda (İstanbul: Siyer Yayınları, 2013), 362, 364; İbn Fakîh, Ahmed b. Muhammed, Kitâbü'l-Büldân, Tahkik Yusuf El-Hâdî (Beyrut: Âlemü'l-Kütüb, 1416), 537; Kudâme b. Ca'fer, Kudâme b. Ziyâd el-Kâtib el-Bağdâdî, Kitâbü'l-Harâc ve Sinâ'ati'l-Kitâbe, Tahkik Muhammed Hüseyin Zebîdî (Bağdad: Dârü'l-Reşîdü'n-Neşr, 1981), 374-75.

Belâzûrî, Fütûhu'l-Büldân, 301; Belâzûrî, Fütûhu'l-Büldân (Ülkelerin Fetihleri), 351.

7 İbnü'l-Esîr, Ebü'l-Hasen İzzüddîn Alî b. Muhammed b. Muhammed eş-Şeybânî el-Cezerî, el-Kâmil fi 't-Tarih, çev. Ahmet Ağırakça, c. III (İstanbul: Bahar Yayınları, 1991), 427.

8 Yâkût el-Hamevî, Şihâbeddin Yakut b. Abdullah el-Rûmî, Mu'cemü'l-Büldân, c. III (Beyrut: Dâru Sâdr, 1995), 118; Hamdullah Müstevfî, Nüzhetu'l-Kulûb, Nşr. Guy Le Strange (London-Leiden, 1915), 52; Makdisî, Muhammed b. Ahmed, Ahsenü’t-Tekâsîm fî Marifetü'l-Ekâlîm (Leiden: Brill, 1906), 385; İbnü'l-Esîr, Ebü'l-Hasen İzzüddîn Alî b. Muhammed b. Muhammed eş-Şeybânî el-Cezerî, el-Kâmil fi't-Tarih, çev. M. Beşir Eryarsoy, c. IV (İstanbul: Bahar Yayınları, 1991$), 55$. 
üzerine Attâb b. Verkâ, Rey üzerine yürüyerek şehir halkını mağlup etti ve Rey şehrini kılıç zoruyla fethedip her şeyi ganimet olarak aldı. ${ }^{10}$ Halife Abdülmelik devrinde 71 (690-91) yılında Yezîd b. Ruveym, Rey valisi olarak tayin edildi. ${ }^{11}$ Ancak bu esnada Rey'de Haricilerin çıkardığı karışıklıklar devam ediyordu. 77 (696-97) tarihinde Rey valisi Adiy b. Ziyad idi. ${ }^{12}$ Haccac b. Yusuf'un Irak valiliği döneminde 83 (702-03) yılında Ömer b. Ebi’s-Salt, yaşanan karışıklıklardan dolayı Rey şehrini ele geçirdi. Bunun üzerine Kuteybe b. Müslim Rey’e doğru yola çıktı ve ardından iki taraf arasında meydana gelen savaşı Kuteybe b. Müslim kazandı ve Ömer b. Ebi’s-Salt şehirden firar etti. ${ }^{13} \mathrm{Bu}$ tarihten itibaren Emevîler'in yıkılışına kadar şehirde çeşitli problemler yaşandı.

Emevîler döneminde şehirde önemli bir takım toplumsal ve demografik gelişmeler de yaşanıyordu. VII. yüzyıl sonlarında bazı Arap kabileleri Rey’de yerleşmeye başladılar. Arkeolojik çalışmalar, Rey’in şehir planının gelişimi ve topoğrafyası incelendiğinde kentin çekirdek yapısının, Kale ve Şehristan; güney ve doğu yönünde genişlediğini göstermektedir. Muhtemelen bu duruma buraya yerleşen Arap kabileleri neden olmuştu. ${ }^{14}$

\section{Abbâsîler'in Kuruluşundan Me'mûn'un Hilafetine Kadar Rey}

Rey şehrinin Emevî idaresinden Abbâsîler'e geçişi sırasında çok fazla karışıklık yaşanmamıştır. Abbâsî ihtilal hareketinin başladığı esnada Horâsân Eyaleti, Nasr b. Seyyâr'ın idaresi altında idi. ${ }^{15} 131$ (748) yılında Horâsân' daki şehirlerin Abbâsîler hâkimiyetine geçtiği sırada Abbâsî nakib ve kumandanlarından Kahtabe b. Şebîb, oğlu Hasan'1 Rey üzerine gönderdi. Nasr b. Seyyâr, aldığg mağlubiyetten sonra Rey’e geldiği zaman şehrin valisi Habîb b. Yezîd en-Nehşelî idi. Nasr, Rey'de iki gün kaldıktan sonra hastalandı ve ardından Sâve'ye gittiği sırada burada vefat etti. ${ }^{16}$ Abbâsî askerlerine karşı koyamayacağını bilen Habîb b. Yezîd en-Nehşelî ve Rey’deki Emevî idarecileri şehri terk etmek zorunda kaldılar ve akabinde Kahtabe'nin oğlu Hasan, Safer 131 (Ekim 748) tarihinde Rey'e girdi. Ardından Kahtabe b. Şebîb de Rey’e geldi ve şehrin ele geçirildiğini bir mektupla Ebû Müslim Horâsânî’ye bildirdi. Rey’de Abbâsî idaresinin kurulması üzerine Emevî taraftarlarının çoğu şehri terk etmek zorunda kaldılar. Kahtabe b. Şebîb, Rey’de bir takım ihtiyat tedbirleri aldı. Daha sonra Ebû Müslim Horâsânî, Rey’deki Emevî taraftarlarının mallarına el konulmasını emretti. ${ }^{17}$ Böylelikle çok fazla kan dökülmeden Rey şehri, Emevîlerden Abbâsîlere

10 İbn Haldûn, Abdurrahman b. Muhammed, Tarihu İbn Haldûn (el-İber), Tahkik Halil Şehâde ve Süheyl Zekkâr, c. III (Beyrut: Dârü'l-Fikr, 1421), 186; İbnü'l-Esîr, el-Kâmil fi't-Tarih, IV, 259, 261.

11 Taberî, Ebû Ca'fer Muhammed b. Cerîr, Tarih-i Taberî (Tarihü'l-Rusul ve'l-Mülûk), Tahkîk Muhammed Ebûlfazl İbrahim, c. VI (Beyrut: Dâru't-Turâs, 1387), 164; İbnü'l-Esîr, el-Kâmil fi 't-Tarih, IV, 300.

12 İbnü'l-Esîr, el-Kâmil fi't-Tarih, IV, 392.

13 Taberî, Tarih-i Taberî (Tarihü'l-Rusul ve 'l-Mülûk), VI, 378; İbnü'l-Esîr, el-Kâmil fi't-Tarih, IV, 443-44.

14 Rocco Rante, Rayy: From Its Origins to the Mongol Invasion: an Archaeological and Historiographical Study (Brill, 2014), 16.

15 Nasr b. Seyyâr, Emevîler'in son Horâsân valisidir. Daha fazla bilgi için bkz.gm Nahide Bozkurt, "Nasr b. Seyyâr", DİA, c. XXXII (İstanbul, 2006), 415-16.

16 Mesûdî, Ebî'l-Hasan Ali b. el-Hüseyin b. Ali, Mürûcü'z-Zeheb ve Meâ'dini'l-Cevher, Tahkîk Esed Dâğer, c. III (Kum: Dârü'lHicre, 1409), 243; İbn Kesîr, Ebû'l-Fidâ İmâdüddîn İsmâil bin Şihâbüddîn Ömer, el-Bidâye ve'n-Nihaye (Büyük İslam Tarihi), çev. Mehmet Keskin, c. X (İstanbul: Çağrı Yay., 1994), 70; Hamdullah Müstevfî Kazvînî, Tarih-i Güzîde, Tashih Abdulhüseyin Nevâî, 3. baskı (Tahran: Emîr Kebîr, 1364), 288; İbnü’l-Esîr, Ebü'l-Hasen İzzüddîn Alî b. Muhammed b. Muhammed eşŞeybânî el-Cezerî, el-Kâmil fi't-Tarih, çev. Yunus Apaydın, c. V (İstanbul: Bahar Yayınları, 1986), 325; İ'timâdü's-Saltana, Muhammed Hasan Hân, Tarih-i Muntazam-i Nâsırî, c. I (Tahran: Donyâ-yi Ketâb, 1367), 130; Şebânkârâi, Muhammed bin Ali bin Muhammed, Mecmau'l-Ensab, Mir Haşim Muhaddis, c. I (Tahran, 1381), 337.

17 Dineverî, Ebû Hanîfe, el-Ahbâru 't-Tıvâl, Tahkîk Abdülmün'im Âmir (Kahire: Dâru İhyâ-i el-Kütübü'l-Arabî, 1960), 364; İbn Kesîr, el-Bidâye ve'n-Nihaye (Büyük İslam Tarihi), X, 71; İbnü'l-Esîr, el-Kâmil fi't-Tarih, V, 326. 
geçmiş oldu.

Abbâsîler'in ilk halifesi Ebû'l-Abbâs es-Seffâh zamanında Rey'in ilk valisi Nasr b. Abdülaziz el-Huzâ'î olmuştur. Ancak bu sırada daha çok yeni olan Abbâsî hilafeti içinde bazı problemler mevcuttu. Ebû Müslim Horâsânî'nin öldürülmesinden sonra Halife Ca'fer b. Mansûr, Nasr b. Abdülaziz'e Ebû Müslim'in dilinden bir mektup yazarak şehrin idaresini Ebî Ubeyde’ye vermesini söyleyince Nasr, şehrin idaresini Ebî Ubeyde'ye teslim etti ve ardından Ebî Ubeyde, Mansûr'un emri ile Nasr' 1 ortadan kaldırd1. ${ }^{18}$ Sem'ânî'nin verdiği bilgiye göre XII. yüzyılda Rey'de Nasrâbâd adında bir mahallenin bulunduğu anlaşılmaktadır. ${ }^{19}$ Yakût'a göre Nasrâbâd Mahallesi, Nasr b. Abdülaziz'e nisbet edildiği için bu adı almıştır. ${ }^{20}$

Abbâsîler döneminde Rey'de ilk karışıklık Ebû Müslim Horâsânî’nin öldürülmesinden sonra ortaya çıktı. 137 (755) tarihinde Ebû Müslim'in öldürülmesinden sonra Sinbâd, onun intikamını almak üzere Horasân'da isyan etti. Çevresinde birçok kişi toplayarak önce Nişabur ve Kûmis, ardından Rey'i ele geçirdi. Sinbâd, Rey'e geldikten sonra Ebû Müslim'in hâzinelerine de sahip oldu. Ebû Müslim, Ebû'l-Abbâs'ın yanına gittiği sırada hâzinelerini Rey’de bırakmıştı. Sinbâd, Rey'de kadınları esir edip mallarını yağma etti; ancak tüccarlara dokunmadı. Sinbâd'ın isyanına karşı Halife Mansûr, Cumhûr b. Mirrâr el-İclî’yi on bin askeriyle onun üzerine gönderdi. İki ordu Hemedân ve Rey arasında bir çölde karşılaştılar. Meydana gelen bu savaşta Sinbâd ağır bir mağlubiyet aldı ve taraftarlarından yaklaşık 60 bin kişi öldürüldü. Ardından Sinbâd, Taberistân'la Kûmis arasında bir yerde ortadan kaldırıldı. ${ }^{21}$ Böylelikle Sinbâd isyanı bastırıldıktan sonra Rey şehri yeniden Abbâsî hâkimiyetine geçti.

Rey'deki sıkıntılar Sinbâd'ın ortadan kaldırılmasından sonra da devam etti. 138 (756) yılında Sinbâd'ı ortadan kaldıran Cumhûr b. Mirrâr el-İclî, Rey'de Halife Mansûr'a isyan etti. Cumhûr, Sinbâd'ı yenilgiye uğrattığında Sinbâd'ın ordugâhında bulunan her şeyi ele geçirmişti. Bunlar arasında Ebû Müslim'in hâzineleri de vardı. Cumhûr, bunları halifeye göndermeyerek başkaldırması üzerine Mansûr, ona karşı Muhammed b. Eş'as'ı büyük bir ordu ile Rey'e sevketti. Cumhûr, kendisine karşı bir ordunun gönderildiğini haber alınca Rey’den ayrılarak İsfahân'a hareket etti. Cumhûr'un ayrılmasından sonra Muhammed b. Eş'as, Rey şehrine girdi, Cumhûr ise İsfahân şehrini ele geçirdi. Muhammed daha sonra Cumhûr üzerine asker göndererek kendisi Rey'de kaldı. Ardından iki ordu Rey ile İsfahân arasında bulunan Kasr-ı Fîrûzân denilen yerde karşılaştılar. Bu savaşta Cumhûr yenilgiye uğradı ve Azerbaycân'a sığındı. Fakat bir süre sonra arkadaşları tarafından öldürülerek başı Mansûr'a getirildi. ${ }^{22}$

18 Yâkût el-Hamevî, Mu'cemü'l-Büldân, V, 287.

19 Sem'ânî, Abdülkerim b. Muhammed b. Mansûr, el-Ensâb, c. XIII (Haydarabâd: Meclis-i Dâiretü'l-Muarrifü'l-Osmaniyye, 1382), 108.

20 Yâkût el-Hamevî, Mu'cemü'l-Büldân, V, 287.

21 Taberî, Tarih-i Taberî (Tarihü'l-Rusul ve'l-Mülûk), VII, 495; İbn Miskeveyh, Ebû Ali Ahmed b. Muhammed, Tecâribü'lÜmem, Tahkik Ebû'l-Kâsım İmâmî, c. III (Tahran: Suroş, 1379), 368; İbn Tağrîbirdî, Cemâleddîn Ebû'l-Mehâsin, enNücûmu'z-Zâhire fì Mülûk-i Misr ve'l-Kâhire, c. I (Misır: Vezâretü's-Sekâfe ve'l-İrşâdü'l-Kavmî, y.y.), 347; Zehebî, Şemseddîn Muhammed bin Ahmed bin Osman, Tarihü'l-İslâm ve Vefâyat el-Meşâhîr ve'l-Âlâm, Tahkik Ömer Abdusselâm Tedmürî, c. VIII (Beyrut: Dâru'l-Kitabu'l-Arabî, 1413), 359; İbn Kesîr, el-Bidâye ve'n-Nihaye (Büyük İslam Tarihi), X, 12728; İbnü'l-Esîr, el-Kâmil fi't-Tarih, V, 392.

22 Taberî, Tarih-i Taberî (Tarihü'l-Rusul ve'l-Mülûk), VII, 497; İbnü'l-Cevzî, Cemâleddîn Ebû'l-Ferec Abdurrahmen b. Ali b. Muhammed, el-Muntazam fî Târîhi'l-Ümem ve'l-Mülûk, Tahkik Muhammed Abdülkadir Atâ ve Mustafa Abdülkadir Atâ, c. VIII (Beyrut: Darü'l-Kütübü'l-İlmiyye, 1412), 20; Sibt İbnü'l Cevzî, Şemseddin Ebu'l-Muzaffer Yusuf b. Kızoğlu, Mirâtü’zZaman fî Tarihü'l-Âyân, Tahkik İbrahim Ez-Zeybek, c. XII (Dımaşk: Dârü'l-Risâletü'l-Âlemiyye, 1434), 87; İbn Haldûn, Tarihu İbn Haldûn (el-İber), III, 232; İbnü'l-Esîr, el-Kâmil fi 't-Tarih, V, 394. 
Ebû Müslim'in öldürülmesinden sonra İran topraklarında kargaşa ve sıkıntılar devam ediyordu. Bundan dolayı Halife Mansûr oğlu Muhammed Mehdî’yi Horâsân'a göndermek zorunda kaldı. 141 (758-9) yılında Horâsân Valisi Abdülcebbar b. Abdurrahman'in Halife Mansûr'a başkaldırmasından dolayı Mansûr oğlu Muhammed Mehdî’yi onun üzerine yolladı. Mehdî önce Rey şehrine gelerek burada bazı hazırlıklarda bulundu. ${ }^{23}$ Horâsân'da Abdülcebbâr'ın mağlup edilmesinden sonra Mansûr, Mehdi'ye bir mektup yazarak Taberistân'a bir sefer düzenlemesini ve yolda Rey'de konaklamasını bildirdi. ${ }^{24}$ Mehdî, Horâsân'dan döndükten sonra 144 (761-2) yılında kadar Rey'de kaldı ve ardından Bağdâd'a döndü. Daha sonra 146 (763-4) yılında yeniden Rey’e geldi ve 151 (768-9) yılında kadar burada kald1. ${ }^{25}$

Mehdî’nin Rey'e gelmesi şehir açısından önemli gelişmelere sahne oldu. Rey'de basılan sikkelerde 149 (766-7) yılından itibaren Muhammediyye adı kullanılmaya başlandı. ${ }^{26}$ Bununla birlikte Mehdî eski Rey şehrinin yerleşimin olduğu yerde, Bîbî Şehrbânû Dağı'nın eteklerinde bir imar faaliyeti başlattı. ${ }^{27}$ Mehdî şehrin etrafını hendeklerle çevirtti ve Ammar b. Ebî'l-Hasîb'e büyük bir cami yaptırdı. Şehrin etrafi alçak duvarlarla çevrildi ve tuğladan yapılan bu duvar şehri ikiye ayırdı ve buraya Muhammediyye adı verildi. Rey halkı duvarın iç kısmındaki bölüme İç Şehir (Medinetü'd-Dâhile); duvarın ötesine de Dış Şehir (Medinetü'l-Hârice) adını verdiler. Bu binaların yapımı 158 (775) y1linda tamamland.. ${ }^{28}$

Muhammediyye esas itibariyle üç kısımdan oluşmaktaydı. Birinci kısım Şehristan veya Medine-i Dâhile denilen İç Şehir; ikinci kısım Kale veya Medine-i Hârice denilen Dış Şehir; üçüncü kısım Rabaz veya Pazar diye adlandırılan bölümdü. ${ }^{29}$ Mehdî, Muhammediyye'nin içinde Dış şehir kısmında bulunan Zenbedî Kale'sini tamir ettirerek buraya geldi. Bu kale daha sonra hapishane olarak kullanıld1. ${ }^{30}$ Muhammediyye daha sonra Cibâl bölgesinin en önemli darphanelerinden biri oldu. Bundan dolayı burada basılan çoğu sikkede Muhammediyye ismi ve dönemin halifesinin adı görülmektedir. ${ }^{31}$ Esas itibariyle Rey tarihinde Mehdî’nin ayrı bir yeri bulunmakta olup Muhamediyye'nin inşasından sonra şehir birçok açıdan gelişme göstermiştir.

İbn Kesîr, el-Bidâye ve 'n-Nihaye (Büyük İslam Tarihi), X, 133; İbnü'l-Esîr, el-Kâmil fi't-Tarih, V, 412.

24 Taberî, Tarih-i Taberî (Tarihü'l-Rusul ve'l-Mülûk), VII, 508-9; İbn Miskeveyh, Tecâribü'l-Ümem, III, 376; İbnü'l-Cevzî, elMuntazam fî Târîhi'l-Ümem ve'l-Mülûk, VIII, 30-31; Zehebî, Tarihü'l-İslâm ve Vefâyat el-Meşâhîr ve'l-Âlâm, IX, 7; İbn Haldûn, Tarihu İbn Haldûn (el-ïber), III, 234; İbnü'l-Esîr, el-Kâmil fi't-Tarih, V, 412.

25 Hamza b. Hasan İsfahânî, Tarih-i Peyâmberân ve Şâhân, çev. Cafer Şiâr (Tahran: İntişârât-1 Bonyâd-1 Ferheng-i İran, 1346), 200.

26 George Carpenter Miles, The Numismatic History of Rayy, c. II (American Numismatic Society, 1938$), 31$.

27 Hüseyin Kerîmân, Rey-i Bâstân, c. II (Tahran: Silsile-i İntişârât-i Encümen-i Âsâr-i Millî, 1349), 130; Mahmûdpûr ve Muhammedî, "Rey", 4.

28 Ya'kûbî, Ahmed b. İshâk, Kitâbü'l-Büldân, Tahkik Muhammed Emin Zanâvî (Beyrut: Daru'l-Kutubu'l-İlmiyye, 1422), 90; Türkçe trc., Ülkeler Kitabı, çev. Murat Ağarı (İstanbul, 2002), 57; Zekeriyyâ Kazvînî, Zekeriyyâ b. Muhammed, Asârü’l-Bilâd ve Ahbârü'l-İbâd (Beyrut: Dâru Sâdr, 1998), 375;Mücmelü't-Tevârîh ve'l-Klsas, Tashih Melikü’ş-Şuerâ Behâr (Tahran: Kelâle-i Hâver, y.y.), 43; Yâkût el-Hamevî, Şihâbeddin Yakut b. Abdullah el-Rûmî, Müşterek-i Yâkût Hamevî, çev. Muhammed Pervîn Gonâbâdî (Tahran: Emîr Kebîr, 1362), 167; Yâkût el-Hamevî, Mu'cemü'l-Büldân, III, 118; Belâzûrî, Fütûhu'l-Büldân, 311; Belâzûrî, Fütûhu'l-Büldân (Ülkelerin Fetihleri), 364; İbn Fakîh, Kitâbü 'l-Büldân, 537; Kudâme b. Ca'fer, Kitâbü'l-Harâc ve Sinâ'ati'l-Kitâbe, 375.

29 Hüseyin Kerîmân, Rey-i Bâstân, c. I (Tahran: Silsile-i İntişârât-i Encümen-i Âsâr-i Millî, 1345), 173.

30 Belâzûrî, Fütûhu'l-Büldân, 311; Belâzûrî, Fütûhu'l-Büldân (Ülkelerin Fetihleri), 364; Ancak Kudâme b. Cafer'e göre bu kale Ferruhân Kalesi'dir. Kudâme b. Ca'fer, Kitâbü'l-Harâc ve Sinâ'ati'l-Kitâbe, 375.

31 Guy Le Strange, The Lands of the Eastern Caliphate: Mesopotamia, Persia, and Central Asia from the Moslem conquest to the time of Timur (Cambridge, 1930), 214. 
Mehdî döneminde 165 (781-2) y1lında Rey valisi Halef b. Abdullah azledilerek yerine Ca'fer'in azadlı kölesi Îsâ tayin edildi. ${ }^{32}$ Öte yandan 166 (782-3) y1lında ise Rey valiliğinde Mehdî'nin azatlısı olan Sa'd bulunmaktaydı. ${ }^{33}$

Mehdî’nin vefatından sonra yerine Mûsâ Hâdî halife oldu. Hâdî’nin 147 (764) yılında Rey şehrinde doğduğu tahmin edilmektedir. ${ }^{34}$ Mûsâ Hâdî, babasının sağlığında Rey’e giderken Kazvîn yakınlarında bir şehir kurulmasını emretmiş ve kurulan bu yeni şehir Medine-i Musa diye anılmıştır. ${ }^{35}$ Yâkût el-Hamevî, Mûsâ Hâdî'nin babasının hilafeti zamanında ona nisbet edilen Mûsâ Âbâd adlı bir karyeyi zikretmektedir. ${ }^{36}$ Ya'kûbî ise Rey şehrinden bahsederken Nehr-i Musa adlı bir nehirden bahsetmektedir. ${ }^{37}$ Muhtemelen bu nehrin adı Mûsâ Hâdî'den gelmektedir.

Mûsâ Hâdî'nin vefatından sonra yerine kardeşi Hârûn Reşîd halife oldu. Hârûn Reşîd, 145 (763) veya 149 (766) yılında Rey'de dünyaya gelmiştir. ${ }^{38}$ Abbâsî halifeleriniin en önemli ve meşhurlarından olan Hârûn Reşîd, Rey şehrine ayrı bir önem vermiştir. Bazı İslâm coğrafyacılarına göre Hârûn Reşîd, Rey şehrini dünyanın dört menzilinden biri saymaktaydı. ${ }^{39}$

Hârûn Reşîd döneminde Rey'de önemli gelişmeler yaşanmıştır. 176 (792-3) tarihinde Yahya b. Abdullah, Deylem'de ayaklanınca Hârûn Reşîd, Fazl b. Yahyâ'yı elli bin kişilik bir kuvvetle Yahya'nın üzerine gönderdi ve ardından Cürcân, Taberistân, Rey de dahil, bir kısım yerlerin valiliklerini ona verdi. ${ }^{40}$ Ancak Fazl, Rey'deki görevinden 180 (796-7) yılında azledildi ve yerine Muhammed b. Yahya b. Hâris tayin edildi. ${ }^{41}$ Bununla birlikte Hârûn Reşîd'in hilafetinin son yıllarında Rey'de birtakım karışıklıklar ortaya çıktı. 189 (805) yılında Horâsân Valisi Ali b. İsa Mâhân'ın Horâsân halkına zulmetmesi ve halkına kötü davranması üzerine Horâsân'ın ileri gelenleri Hârûn'a bir mektup göndererek Ali b. İsa'nın kendilerine kötü muamele ettiğini, zulüm yaptığııı, haksız yere mallarını ellerinden aldığını şikâyet ettiler. Bundan dolayı Hârûn, hem Ali b. İsa Mâhân meselesi, hem de Rey'deki problemleri çözmek amaciyla Cemâziyelevvel 189 (Nisan 805) tarihinde oğulları Me'mûn ve Kasım ile birlikte Rey'e hareket ederek şehre geldi. Hârûn Reşî̀, Ali b. İsa'nın Horasan'dan gelişine kadar Rey'de dört ay kaldı. Ali b. İsa, halifenin gönlünü kazanmak için Rey'e geldiği zaman ona bol miktarda hediyeler ve büyük değeri olan kıymetli

32 Taberî, Tarih-i Taberî (Tarihü'l-Rusul ve'l-Mülûk), VIII, 153; İbnü'l-Esîr, Ebü'l-Hasen İzzüddîn Alî b. Muhammed b. Muhammed eş-Şeybânî el-Cezerî, el-Kâmil fi't-Tarih, çev. Abdullah Köşe, c. VI (İstanbul: Bahar Yayınları, 1991), 64; İbnü’lCevzî, el-Muntazam fî Târîhi'l-Ümem ve'l-Mülûk, VIII, 273; İbn Haldûn, Tarihu İbn Haldûn (el-İber), III, 266; Sibt İbnü'1 Cevzî, Mirâtü'z-Zaman fì Tarihü'l-Âyân, XII, 342.

33 İbnü'l-Esîr, el-Kâmil fi't-Tarih, VI, 70.

34 Suyûtî, Celâleddîn Abdurrahman, Tarihü'l-Hulefâ, Tahkik Hamdî El-Demirdâş (Mekke: Mektebe-i Nizâru Mustafa Elbâz, 1425), 207; Nahide Bozkurt, "Hâdî-İlelhak”, DİA, c. XV (İstanbul, 1997), 16; Yakût el Hamevî’ye göre Hâdî, 146 (763) y1lında Rey’e yakın Sîrvân'da (Şîrvân) doğmuştur. Yâkût el-Hamevî, Mu'cemü'l-Büldân, III, 297.

35 Yâkût el-Hamevî, Mu'cemü'l-Büldân, IV, 343; V, 80; Belâzûrî, Fütûhu'l-Büldân, 315; Belâzûrî, Fütûhu'l-Büldân (Ülkelerin Fetihleri), 368; İbn Fakîh, Kitâbü'l-Büldân, 559.

36 Yâkût el-Hamevî, Mu'cemü'l-Büldân, V, 222.

37 Ya'kûbî, Kitâbü'l-Büldân, 90; Ya'kûbî, Ülkeler Kitabı, 57.

38 Taberî, Tarih-i Taberî (Tarihü'l-Rusul ve'l-Mülûk), VIII, 230; İbn Miskeveyh, Tecâribü'l-Ümem, III, 503; İbnü'l-Cevzî, elMuntazam fí Târîhi'l-Ümem ve 'l-Mülûk, VIII, 318; İbnü'l-Verdî, Zeyneddîn Ömer b. Muzaffer b. Ebî'l-Fevâris, Tarihu İbnü'lVerdî, c. I (Beyrut: Daru'l-Kutubu'l-İlmiyye, 1417), 194; İbnü'l-Esîr, el-Kâmil fi't-Tarih, VI, 98.

39 Makdisî, Ahsenü't-Tekâsîm fì Marifetü'l-Ekâlîm, 385; İbn Fakîh, Kitâbü'l-Büldân, 545; Yâkût el-Hamevî, Mu'cemü'l-Büldân, III, 206.

40 Taberî, Tarih-i Taberî (Tarihü'l-Rusul ve 'l-Mülûk), VIII, 242; İbn Miskeveyh, Tecâribü'l-Ümem, III, 507; İbn Haldûn, Tarihu İbn Haldûn (el-İber), III, 274; İbn Tağrîbirdî, en-Nücûmu'z-Zâhire fî Mülûk-i Misr ve 'l-Kâhire, II, 62; İbn Kesîr, el-Bidâye ve 'nNihaye (Büyük İslam Tarihi), X, 281; İbnü'l-Esîr, el-Kâmil fi 't-Tarih, VI, 115.

41 Taberî, Tarih-i Taberî (Tarihü'l-Rusul ve'l-Mülûk), VIII, 266; İbnü'l-Cevzî, el-Muntazam fì Târîhi'l-Ümem ve'l-Mülûk, IX, 48. 
mallar takdim etti. Ayrıca, Hârûn'un yanında bulunan yakınlarına, çocuklarına, kâtiplerine ve kumandanlarına kıymetli şeyler, mücevherler ve benzeri hediyeler verdi. Bunun üzerine Ali b. İsa hakkındaki kanaati değișen Hârûn Reşîd, onu tekrar Horasân'a gönderdi. ${ }^{42}$ Ardından Abdullah b. Mâlik'i, Taberistân, Rey, Demâvend, Kûmis ve Hemedân valiliklerine tayin etti. ${ }^{43}$

Hârûn Reşîd'in ölümünden sonra oğulları Me'mûn ve Emîn arasında meydana gelen mücadelelerden en çok etkilenen şehirlerden biri de Rey oldu. 194 (809-10) yılında Rey şehrinin âmili Abbâs b. Abdullah b. Mâlik idi. Bu tarihlerde Rey şehri üzerinde Me'mûn'un nüfuzu daha çoktu. Çünkü Me'mûn, Horâsân ve bu bölgeden Hemedân'a kadar olan yerlerin valisi idi. Halife Emîn, Abbâs b. Abdullah b. Mâlik'e bir mektup göndererek onu denemek maksadiyla Rey'de bulunan enteresan fidan veya hurma tatlısı çeşitlerini kendisine bir mektupla bildirmesini istedi. Abbâs b. Abdullah, Emîn'in emrini yerine getirerek kendisine bir mektupla bu hususta bilgi verdi; fakat bunu Me'mûn'dan gizli tuttu. Bu durumdan haberdar olan Me'mûn, Abbâs b. Abdullah'1 azlederek yerine Hasan b. Ali'yi tayin etti. ${ }^{44}$ Emîn ile Me'mûn arasındaki ihtilaf şiddetlenince Me'mûn, Rey, Nîşâbûr ve diğer yerlerdeki âmillerine birer mektup göndererek hazırlanmalarını istedi. Bu sırada Rey civarındaki bölgelerde kıtlık bulunması sebebiyle, Me'mûn burada bulunan askerlerin taşkınlık edip sağa sola saldırmamaları için onlara büyük ihsanlarda bulundu. Ardından teşkil ettiği ordunun başına Tahir b. Hüseyin' $i^{45}$ getirdi. Tahir b. Hüseyin süratli bir yürüyüşle Rey’e geldi ve şehirde konaklamaya başladı. ${ }^{46}$ Bunu müteakiben 195 (811) y1lında halife Emîn'in kumandanı Ali b. İsa ile Me'mûn'un kumandanı Tahir b. Hüseyin arasında Rey yakınlarında meydana gelen savaşı Tahir b. Hüseyin kazand1 ${ }^{47}$ Bu mücadeleden kısa bir süre sonra Halife Emîn ortadan kaldırıldı ve yeni halife Me'mûn oldu. Böylelikle Rey'de geçici de olsa yeniden bir huzur ve sükûnet dönemi başladı.

\section{Me'mûn'dan IX. Yüzyılın Sonuna Kadar Rey}

Halife Me'mûn, 205 (821) tarihinde Tahir b. Hüseyin'i Horâsân valiliğinin başına getirdi. Bu sırada Rey, Taberistan, Kûmis ve Kirman gibi yerler de Tahir'in idaresinde idi. Böylelikle hem Tâhirîler hanedanının temelleri atıldı, hem de Rey şehrinin idaresi Tâhirî hanedanına geçmiş oldu. Tahir b. Hüseyin'in 207 (822) yılında vefatından sonra Me'mûn, yerine oğlu Talha'yı Horasan valiliğine tayin etmek zorunda kaldı. Ancak bu sırada Horâsân'daki isyanlar nedeniyle Tahir b. Hüseyin'in diğer oğlu Abdullah b. Tâhir, Horâsân valiliğine getirildi. ${ }^{48} 210$ (825-6) tarihinde Me'mûn, Horâsân'dan Irak'a dönerken bir müddet Rey'de konakladı. Bu sırada Rey halkının müracaatı üzerine şehrin vergilerinden bir miktar indirim yaptı. ${ }^{49} \mathrm{Abdullah} \mathrm{b.} \mathrm{Tâhir'in} \mathrm{idaresi} 230$

42 Ya'kûbî, Ahmed b. İshâk, Tarihü'l-Ya'kûbî, c. II (Beyrut: Dâru Sâdr, y.y.), 425; İbnü'l-Esîr, el-Kâmil fi't-Tarih, VI, 173-74; Taberî, Tarih-i Taberî (Tarihü'l-Rusul ve'l-Mülûk), VIII, 315-16; Sibt İbnü'l Cevzî, Mirâtü'z-Zaman fî Tarihü'l-Âyân, XIII, 118; İbn Miskeveyh, Tecâribü'l-Ümem, III, 553-54; İbnü'l-Cevzî, el-Muntazam fî Târîhi 'l-Ümem ve'l-Mülûk, IX, 161.

43 Taberî, Tarih-i Taberî (Tarihü'l-Rusul ve'l-Mülûk), VIII, 316-17; İbnü'l-Esîr, el-Kâmil fi't-Tarih, VI, 175; Sibt İbnü'l Cevzî, Mirâtü'z-Zaman fî Tarihü'l-Âyân, XIII, 119.

44 İbnü'l-Esîr, el-Kâmil fi 't-Tarih, VI, 203.

45 Tahir b. Hüseyin hakkında bkz. Hasan Kurt, "Tâhir b. Hüseyin”, DİA, c. XXXIX (İstanbul, 2010), 399-400.

46 İbnü'l-Esîr, el-Kâmil fi't-Tarih, VI, 204, 208.

47 Halife b. Hayyât, Tarihu Halife b. Hayyât, Tahkik Ekrem Ziyâ El-Ömerî (Riyad: Dâru Tîbe, 1985), 557; Taberî, Tarih-i Taberî (Tarihü'l-Rusul ve'l-Mülûk), VIII, 391; Ebû'l-Fidâ, el-Melikü'l-Müeyyed İmâdüddîn İsmâîl b. Alî, el-Muhtasar fi Ahbârü'lBeşer, c. II (Kahire, 1325), 19; Zehebî, Tarihü'l-İslâm ve Vefâyat el-Meşâhîr ve'l-Âlâm, XIII, 25-26; İbnü'l-Esîr, el-Kâmil fi 't-Tarih, VI, 216; İbn Haldûn, Tarihu İbn Haldûn (el-İber), III, 292; İbn Tağrîbirdî, en-Nücûmu'z-Zâhire fì Mülûk-i Misr ve'lKâhire, II, 149; Sibt İbnü'l Cevzî, Mirâtü'z-Zaman fî Tarihü'l-Âyân, XIII, 242.

48 Hasan Kurt, "Tâhirîler”, DIA, c. XXXIX (İstanbul, 2010), 403; Kurt, “Tâhir b. Hüseyin”, 400.

49 Yâkût el-Hamevî, Mu'cemü'l-Büldân, III, 118; İbnü'l-Esîr, el-Kâmil fi't-Tarih, VI, 345. 
(844) yılına kadar devam etti. Abdullah b. Tâhir Rey, Taberistân, Kirmân, Horasân ve bu şehirlere yakın olan diğer yerleri yönetiyor ve vergilerini topluyordu. Vefat ettiği zaman bu bölgenin geliri yaklaşık kırk milyon dirhem idi. Abdullah'ın vefatı üzerine Halife el-Vâsık bütün bu bölgeye oğlu Tâhir b. Abdullah'1 tayin etti. ${ }^{50}$

Tahir b. Abdullah, 248 (862) y1lında vefat ettikten sonra yerini Muhammed b. Tahir b. Abdullah aldı. Bu dönemde Rey, Tahirîlerin elinde idi. Ancak şehir, Abbâsî hilâfetinin IX. yüzyılın ikinci yarısından itibaren iyice zayıflamasından sonra mahallî hükümdarlıkların rekabet alanı haline geldi. Rey, Taberistan'a hâkim olan Zeydîler'in önce Tâhirîler, daha sonra Abbâsîler'le giriştikleri çatışmaların ortasında kaldı ve oldukça zarar gördü. ${ }^{51} \mathrm{Bu}$ dönemden itibaren şehir, $\mathrm{X}$. yüzyılın başlarına kadar defalarca el değiştirdi. 250 (864) yılında Zeydîler hanedanının kurucusu Dâ'î-yi Kebîr lakaplı Hasan b. Zeyd, Taberistan'da ortaya çıkarak önce Cürcân’1 ele geçirdi, ardından kendisiyle aynı ismi taşıyan akrabalarından Hasan b. Zeyd'i Rey üzerine gönderdi. Hasan b. Zeyd, Rey'e girerek şehri hâkimiyeti altına aldı ve Tâhirîlerin valisini oradan kovup yerine ismi Muhammed b. Ca'fer olan bir Alevîyi görevlendirerek oradan ayrıldı. Ancak Muhammed b. Ca'fer, Rey halkına karşı hoşa gitmeyecek davranışlarda bulundu. Bu esnada Muhammed b. Tahir b. Abdullah, Muhammed b. Mîkâîl'i Rey üzerine gönderdi. Bunu müteakiben Muhammed b. Ca'fer ile Muhammed b. Mîkâîl arasında Rey dışında bir savaş meydana geldi. Bu savaşta Muhammed b. Mîkâîl, Muhammed b. Ca'fer'i mağlup ederek onu esir etti ve şehre girdi. Bunun üzerine Hasan b. Zeyd, Vâcin adında bir adamının komutasında başka bir orduyu Rey üzerine gönderdi. Muhammed b. Mîkâîl, gelen orduya karşı koymasına rağmen hezimete uğrayarak Rey'de kaleye kapandı. Ancak Vâcin ve adamları onu yakalayıp öldürdüler ve böylelikle Rey tekrar Hasan b. Zeyd'in eline geçti. ${ }^{52}$

252 (866) yılında Deylemlîlerin reisi Cestân Ahmed b. İsâ b. Ahmed Alevî, Hüseyin b. Ahmed el-Kevkebî ile birlikte Rey üzerine hücum edip şehir halkından bazılarını öldürerek bazılarını da esir aldı. O sırada Rey'de Abdullah b. Üzeyr valilik görevini yürütüyordu; ancak adı geçen kişilerin şehre hücumları üzerine şehirden kaçmıştı. Rey halkı adı geçen bu kişilerle iki milyon dirhem ödemek şartıyla barış yaptı. Bu parayı alan Ahmed b. İsâ ve Hüseyin b. Ahmed şehri terkedince Abdullah b. Üzeyr şehre geri döndü ve sonrasında Ahmed b. İsa'yı yakalayarak Nîşâbûr'a gönderdi. ${ }^{53}$

Abbâsîlerde yaşanan iç karışıklıklara rağmen Halife Mu’tezz, Zeydîlerin bölgedeki gücünü kırmak maksadıyla Musa b. Boğa’y1, Hasan b. Zeyd üzerine sevk etti. 255 (869) tarihinde Rey’e ulaşan Musa, komutanlarından Müflîh'i Taberistan üzerine gönderdi ve bölgeye ulaşan Müflih, Hasan b. Zeyd'i mağlup etti. Musa'nın Rey'de bulunduğu dönemde halife Mu'tezz, hilafetten indirildi ve yerine halife Mühtedî halife oldu. Yeni halife bu sırada Rey'den Samerra'ya hareket eden Musa'ya bir mektup yazarak Rey'e geri dönmesini ve sınır boylarını korumasını istedi. Fakat Musa bu emre aldırış etmeyerek geri dönmedi. Halife Mühtedî bunun üzerine ona Hâşimoğullarından iki adamı gönderip çektikleri mal sıkıntısını ve kendisinin Rey’den ayrılması üzerine geride bırakacağı Alevî (Zeydî) tehlikesini hatırlattı; ancak Mûsâ yine de onların dediklerine kulak asmayarak Rey’e

50 Taberî, Tarih-i Taberî (Tarihü'l-Rusul ve'l-Mülûk), IX, 131; İbn Miskeveyh, Tecâribü'l-Ümem, IV, 278; İbnü'l-Esîr, Ebü'lHasen İzzüddîn Alî b. Muhammed b. Muhammed eş-Şeybânî el-Cezerî, el-Kâmil fi't-Tarih, çev. Ahmet Ağırakça, c. VII (İstanbul: Bahar Yayınları, 1991), 20; İbn Haldûn, Tarihu İbn Haldûn (el-İber), III, 338.

51 Osman G. Özgüdenli, "Rey”, DIA, c. XXXV (İstanbul, 2008), 40; V. Minorsky ve [C. E. Bosworth], "al-Rayy”, $E I^{2}$, c. VIII, 1995, 471; Minorsky, "Rey”, 722.

52 Taberî, Tarih-i Taberî (Tarihü'l-Rusul ve'l-Mülûk), IX, 275; İbn Miskeveyh, Tecâribü'l-Ümem, IV, 334; Aybek ed-Devâdarî, Ebî Bekr bin Abdullah, Kenzü'd-Dürer ve Câmiü'l-Gurer, Tahkik Dorotia Krafolski, c. V (Kahire, 1391), 252-53; İbnü'l-Esîr, el-Kâmil fi't-Tarih, VII, 116; İbn Haldûn, Tarihu İbn Haldûn (el-İber), III, 358; Hamdullah Müstevfî Kazvînî, Tarih-i Güzîde, 326.

53 İbnü'l-Esîr, el-Kâmil fi't-Tarih, VII, 150. 
dönmedi. ${ }^{54}$ Musa b. Boğa'nın Rey'den Samerra'ya dönmesini firsat bilen Hasan b. Zeyd, Ramazan 256 (Ağustos 870) tarihinde yeniden Rey şehrini ele geçirdi. Bunun üzerine halife, Musa b. Boğa’y1 Şevval 256 (Eylül 870) tarihinde Rey’e gönderdi. Ardından Rey'e gelerek Hasan b. Zeyd'i mağlup eden Musa, Rey şehrini tekrar Abbâsî hâkimiyetine ald..$^{55}$

Rey şehrinin sürekli mücadelelere sahne olması ve devamlı el değiştirmesi şehirde yaşanan istikrarsızlı̆̆ın en büyük sebebi idi. Bu durum şehrin X. yüzyılın başında Sâmânîler hâkimiyetine geçişine kadar devam edecektir. 257 (870-71) tarihinde Abdülaziz b. Ebi Dülef' in Rey'i boşaltarak şehirden ayrılması üzerine Taberistân hâkimi Hasan b. Zeyd, "Düleys" lakaplı adamlarından Kâsım b. Ali b. el-Kâsım b. Ali el-Alevî’yi Rey'e gönderdi ve ardından Kâsım şehre gelerek Rey’e hâkim oldu. Ancak Kâsım b. Ali, Rey halkına son derece kötü muamelede bulundu. Bununla birlikte Rey'in demirden olan kale kapılarını sökerek Hasan b. Zeyd'e gönderdi ve şehir üç yıl bu şekilde kald1. ${ }^{56}$

Rey'in 259 (873) yılında yeniden Abbâsî hâkimiyetine geçtiğini görmekteyiz. 259 (873) yılında Musa b. Boğa, Salâbî’yi (veya Salânî) Rey valisi olarak görevlendirdi. ${ }^{57}$ Bu sırada İran'da yeni bir güç ortaya çıkmaktaydı. Bu güç 247 (861) yılında Yakub b. Leys önderliğinde kurulan Saffârîler hanedanı idi. 260 (874) tarihinde Yakub b. Leys, Abdullah es-Siczî ile anlaşmazlığa düşünce Abdullah, Taberistan'a gelerek Hasan b. Zeyd'e sığınmıştı. Abdullah'ın kendisine teslim edilmesini isteyen Yakub b. Leys, teklifinin kabul edilmemesi üzerine Taberistan'a gelerek Hasan b. Zeyd ile mücadele ederek onu mağlup etti. Hasan b. Zeyd'in mağlubiyetinden sonra Abdullah es-Siczî Rey'e gelince, Yakub, Rey'e yakın bir yerde vali Salâbî'ye mektup yazarak Abdullah'1 teslim etmesini istedi. Bunun üzerine Salâbî, Abdullah'1 teslim etti ve Yakub geri döndü. ${ }^{58}$

Salâbî 262 (875-6) yılında vefat etti ve yerine Türk asıllı Kayıglıg, Rey valisi oldu. ${ }^{59} \mathrm{Bu}$ tarihlerde Rey üzerinde daha çok Saffârîler'den Yakub b. Leys'in nüfuzunun daha fazla olduğu görülmektedir. 262 (875-6) tarihinde halifenin kardeşi Ebû Ahmed Mufavvak, Yakub b. Leys'in Bağdâd'a yönelmesi üzerine Bağdâd'da tüccarları toplayıp onlara Ya'kûb'a Horasân, Cürcân, Taberistân, Rey ve Fars illerine ilâve olarak Bağdâd emniyet görevliliğinin de verildiğini bildirdi. ${ }^{60}$

IX. asrın sonlarında Türkler yavaş yavaş Rey ve civarında görünmeye başladılar. 266 (879-80) yılında Asâtekîn adlı Türk, Rey şehri üzerine yürüyerek şehri ele geçirdi ve şehrin valisi Hatlanhacor'u (Taberî'ye göre Talmecûr) şehirden çıkardı. Daha sonra Kazvîn'e saldıran Asâtekîn, şehre girerek Kazvîn halkından bol miktarda mal aldıktan sonra Rey'e döndü ancak Rey halkı onu şehre girmekten menettiler. Bunun üzerine Asâtekîn, halka karşı zor kullanarak şehre girdi. ${ }^{61}$ Öte yandan 267 (880-81) yılında Ahmed b. Abdullah el-Hucustânî Irak'a yürümek maksadıyla Simnân'a gelince Rey halkı kendilerini ondan korumak için müstahkem bir yere kapandı. Ancak Hucustânî, daha sonra yürüyüşünden vazgeçerek Horâsân'a geri döndü. ${ }^{62}$

54 Taberî, Tarih-i Taberî (Tarihü'l-Rusul ve'l-Mülûk), IX, 406; İbnü'l-Esîr, el-Kâmil fi 't-Tarih, VII, 170-71.

55 İbn Kesîr, el-Bidâye ve'n-Nihaye (Büyük İslam Tarihi), XI, 60; İbnü'l-Esîr, el-Kâmil fi't-Tarih, VII, 201; Zehebî, Tarihü'lİslâm ve Vefâyat el-Meşâhîr ve'l-Âlâm, XIX, 22.

56 İbn Haldûn, Tarihu İbn Haldûn (el-İber), III, 324; İbnü'l-Esîr, el-Kâmil fi 't-Tarih, VII, 208.

57 Taberî, Tarih-i Taberî (Tarihü'l-Rusul ve'l-Mülûk), IX, 506.

58 İbn Miskeveyh, Tecâribü'l-Ümem, IV, 439; Taberî, Tarih-i Taberî (Tarihü'l-Rusul ve'l-Mülûk), IX, 510; İbnü'l-Esîr, el-Kâmil fi't-Tarih, VII, 224.

59 Taberî, Tarih-i Taberî (Tarihü'l-Rusul ve'l-Mülûk), IX, 526; İbnü'l-Esîr, el-Kâmil fi't-Tarih, VII, 253.

60 İ̉nü'l-Esîr, el-Kâmil fi 't-Tarih, VII, 241; Abdülkerim Özaydın, “Muvaffak el-Abbâsî”, DİA, c. EK-2 (İstanbul, 2016$), 333$.

61 İbn Miskeveyh, Tecâribü'l-Ümem, IV, 452; Taberî, Tarih-i Taberî (Tarihü'l-Rusul ve'l-Mülûk), IX, 549; İbnü'l-Esîr, el-Kâmil fi 't-Tarih, VII, 277; İbn Kesîr, el-Bidâye ve'n-Nihaye (Büyük İslam Tarihi), XI, 83; İbn Haldûn, Tarihu İbn Haldûn (el-İber), III, 427.

62 Taberî, Tarih-i Taberî (Tarihü'l-Rusul ve'l-Mülûk), VI, 391; İbnü'l-Esîr, el-Kâmil fi't-Tarih, VII, 304. 
Zeydîler'den Hasan b. Zeyd, 270 (884) yılında Âmul'de vefat edince yerine kardeşi Dâi-yi Sagîr Muhammed b. Zeyd geçti. Muhammed b. Zeyd'in 272 (885) tarihinde Rey şehrini elinde bulundurduğu görülmektedir. Cemaziyelevvel 272 ( Kasım 885) tarihinde Kazvîn hâkimi Ezgütekin dört bin kişi ile Kazvîn'den Rey'e hareket etti. Bu sırada Muhammed b. Zeyd'in yanında da Deylemlilerden, Taberistan ve Horasânlılar'dan meydana gelen gayet kalabalık bir ordu vardı. İki taraf arasında yapılan savaşta Muhammed b. Zeyd ağır bir mağlubiyet aldı ve Ezgütekin ve askerleri büyük miktarda ganimet ele geçirdiler. Ezgütekin Rey'e girerek halkından bir milyon dinar alarak adamlarını Rey ve etrafindaki görevlere tayin etti. ${ }^{63}$

275 (888-89) yılında Rey şehrinde Şiîlik revaç bulmaya başladı. Bu zamana kadar şehirde Sünnîlik daha yaygın idi. Daha önce Ezgütekin'in hizmetinde bulunan Ahmed b. Hasan el-Mârdânî, Rey şehrinde Şiîliği yaymaya başlayarak şehirdeki Şiîlere ihsanlarda bulundu ve onları kendine yaklaştırdı. Böylelikle bu tarihten itibaren Rey'de Şiî Mezhebi mensuplarının sayısı artmaya başladi. ${ }^{64}$ Yine bu tarihte Horâsân valisi Râfi' b. Herseme, Muhammed b. Zeyd ile Cürcan ve Kazvîn civarında mücadele ettikten sonra Rey'e gelerek Recep 276 (Kasım 889) tarihine kadar Rey'de ikamet etti. ${ }^{65} 278$ (891-892) yılına kadar şehirde kalan Râfi' b. Herseme, Rey'deki Mehdî Camii'ni tamir ettirdi; ancak onun şehirden ayrılmasından sonra halk burayı harap etti. ${ }^{66}$

279 (892-3) yılında halife Mu'tazıd, Râfi' b. Herseme'ye mektup göndererek Rey'e tâbi olup halifeye bağlı olan köylerin boşaltılmasıni istedi; ancak Râfi' buna yanaşmadı. Bunun üzerine halife Râfi' b. Herseme'yi Horasân valiliğinden azlederek yerine Amr b. Leys'i tayin etti ve Ahmed b. Abdülazîz b. Ebî Dülef'e mektup yazarak Râfi'e karşı savaşa girişip onu Rey'den çıarmasını emretti. Bunu müteakiben Ahmed b. Abdülazîz Rey'e gelerek Râfi'yi mağlûp etti ve Râfi', Cürcân'a kaçtı. Ancak Ahmed b. Abdülazîz'in 280 (893-4) yılında vefat etmesi üzerine Râfi' b. Herseme tekrar Rey'e geldi. Abdülazîz'in iki oğlu Amr ve Bekr, Râfi' b. Herseme'ye karş1 koymalarına rağmen Râfi', onların adamlarından büyük bir kitleyi öldürdü. Bunun üzerine Amr ve Bekr, Cemâziyelevvel 280 (Ağustos 893) tarihinde İsfahân'a kaçtılar. Ardından Râfi b. Herseme Rey'i yeniden ele geçirdi ve bu yılın sonuna kadar şehirde kaldı. ${ }^{67}$

Halife Mu’tazıd Cibâl bölgesi ve Rey'deki problemleri çözmek amacıyla 281 (894-5) tarihinde, oğlu el-Muktefî̀ Ali'ye Rey, Kazvîn, Zencan, Ebher, Kum, Hemedân ve Dînever'i verdi ve bu tarihten itibaren el-Muktefî Ali, Rey'e gelerek burada ikamet etmeye başladı. el-Muktefî'nin Rey'de bulunduğu esnada Amr b. Leys, ona son derece hizmette bulunuyordu. ${ }^{68}$ Bir müddet sonra Râfi' b. Herseme'nin Rey valisi Hasan b. Ali Kûre, el-Muktefî Ali'ye bin adamıla birlikte gelip emân diledi ve Ali b. el-Mu'tazıd da onu yanındakilerle birlikte babasına gönderdi. ${ }^{69} 282$ (895) ve 283 (896) yılında el-Mu'tazıd veziri Ubeydullah b. Süleyman'ı Rey'de bulunan oğluna gönderdi ve oraya varan Ubeydullah da verilen görevi ifa ettikten sonra geri döndü. ${ }^{70} 283$ (896) yılında Râfi' b.

63 İbn Kesîr, el-Bidâye ve'n-Nihaye (Büyük İslam Tarihi), XI, 100; İbn Haldûn, Tarihu İbn Haldûn (el-İber), III, 414-15; İbnü’1Esîr, el-Kâmil fi't-Tarih, VII, 351.

64 Yâkût el-Hamevî, Mu'cemü'l-Büldân, III, 121; Rıza Ferşçiyan, Pîşgâmân-i Teşeyyu der İran (Kum: İntişârât-1 Zâir, 1384), 54; Resûl Ca'feriyân, Tarih-i Gostereş-i Teşeyyu der Rey (Tahran: Âsitân-i Mukaddes-i Hazret-i Abdülazîm, 1371$), 23$.

65 İbnü'l-Esîr, el-Kâmil fi 't-Tarih, VII, 362-63; İbn Haldûn, Tarihu İbn Haldûn (el-İber), III, 415.

66 İbn Fakîh, Kitâbü'l-Büldân, 537-38; Yâkût el-Hamevî, Mu'cemü'l-Büldân, III, 118.

67 Taberî, Tarih-i Taberî (Tarihü'l-Rusul ve'l-Mülûk), X, 31; Mücmelü't-Tevârîh ve'l-Kısas, 367; İbnü'l-Esîr, el-Kâmilffi't-Tarih, VII, 381-82.

68 Mücmelü't-Tevârîh ve'l-Kisas, 370.

69 Mesûdî, Mürûcü'z-Zeheb ve Meâ'dini'l-Cevher, IV, 157; Taberî, Tarih-i Taberî (Tarihü'l-Rusul ve'l-Mülûk), X, 36; İbnü'lEsîr, el-Kâmil fi't-Tarih, VII, 390; Mücmelü't-Tevârîh ve'l-Kısas, 367.

70 Taberî, Tarih-i Taberî (Tarihü'l-Rusul ve'l-Mülûk), X, 41, 47; Sibt İbnü'l Cevzî, Mirâtü'z-Zaman fì Tarihü'l-Âyân, XVI, 180; İbn Miskeveyh, Tecâribü'l-Ümem, IV, 505; İbnü'l-Esîr, el-Kâmil fi't-Tarih, VII, 400. 
Herseme, Amr b. Leys'e karşı mağlup olup ortadan kaldırıldıktan sonra halife Mu'tazıd 284 (897) yılında, Amr b. Leys'e hil'atler ve sancaklar gönderip hediyelerle birlikte onu Rey valiliğine tayin etti. $^{71}$

IX. asırda Mâverâünnehir ve Horasan'da kurulan Sâmânîler, bu yüzyılın sonlarından itibaren Rey'e müdahale etmeye başladılar. 289 (902) yılında Rey valisi Aldatmış et-Türkî'nin şehir halkına kötü davranması üzerine Rey halkı, Sâmânîler'in Taberistan valisi Muhammed b. Harûn'a mektup yazarak onu Rey'e çağırdılar. Bunun üzerine Muhammed b. Harûn, Rey önüne gelerek Aldatmış et-Türkî’yi mağlup etti ve şehri ele geçirdi. ${ }^{72}$

IX. yüzyılda Rey şehrinin vergisinin 10 milyon dirhem olduğu görülmektedir. ${ }^{73}$ Bununla birlikte bu asrın ikinci yarısında Rey şehrinde yaşanan karışıklıklar ve siyasi istikrarsızlık şehrin ekonomisine ve sosyal hayatına darbe vurduğu söylenebilir.

\section{Sonuç}

Hulefâ-yi Râşidîn döneminde İslâm hâkimiyetine geçen Rey, Emevîler döneminde sıkıntılı bir süreç geçirdi. Horâsân'da Abbâsî ihtilalinin başlamasından kısa bir süre sonra Kahtabe b. Şebîb ve oğlu Hasan, Rey şehrini ele geçirdiler. Rey'de Abbâsî idaresinin kurulması üzerine Emevî taraftarlarının çoğu şehri terk etmek zorunda kaldılar (131/748). Ebû Müslim Horâsânî’nin öldürülmesinden sonra kısa bir süreliğine Sinbâd, Rey şehrine hâkim olmasına rağmen Abbâsî ordusu tarafından mağlup edildi (137/755). Ancak Rey'deki sıkıntılar Sinbâd'ın ortadan kaldırılmasından sonra da devam etti. İran topraklarında yaşanan problemlerden dolayı Halife Ca'fer b. Mansûr, oğlu Muhammed Mehdî’yi Horâsân'a gönderdi ve ardından Mehdî, Rey’e gelerek karargâhını kurdu. Mehdî’nin Rey'e gelmesi şehirde bazı değişikliklere sebebiyet verdi. Şehirde 149 (766-7) yılından itibaren basılan sikkelerde Muhammediyye adı kullanılmaya başlandı. Mehdî, eski Rey şehrinin olduğu yerde Muhammediyye adı verilen yeni bir yerleşim yeri inşa ettirdi (158/775). İnşa edilen bu yerleşim yeri Şehristan, Kale ve Rabaz veya Pazar adı verilen üç kısımdan oluşmaktaydı. Rey aynı zamanda bazı Abbâsî halifelerinin doğum yeri idi. Dördüncü Abbâsî halifesi Mûsâ Hâdî ve Abbâsî halifelerinin en önemlilerinden beşinci halife Harun Reşid'in doğum yeri Rey idi. Hârûn Reşîd doğduğu Rey şehrine ayrı bir önem vermekteydi ve hilafeti döneminde iki defa Rey'e gelmişti. Rey şehri Hârûn Reşîd'in ölümünden sonra oğulları Me'mûn ve Emîn arasında meydana gelen çatışmalardan oldukça zarar gördü. Halife Me'mûn zamanında Rey şehrinin idaresi Tahir b. Hüseyin'in eline geçti ve uzun yıllar şehrin idaresi Tahirîlerin elinde kaldı. Ancak şehir, Abbâsî hilâfetinin IX. yüzyılın ikinci yarısından itibaren iyice zayıflamasından sonra mahallî hükümdarlıkların rekabet alanı haline geldi ve Taberistan'a sahip olan Zeydîler'in önce Tâhirîler; daha sonra Abbâsîler'le giriştikleri çatışmaların ortasında kaldı. Bu dönemde Rey, X. yüzyılın başlarına kadar sürekli el değiştirdi. Bu durum şehrin istikrarsızlığının en büyük sebebi idi ve Rey, bu dönemde ekonomik ve sosyal açıdan oldukça zarar gördü. IX. asrın son çeyreğinde Türkler yavaş yavaş Rey ve civarında görünmeye başladılar. Yine bu dönemde şehir yaşanan çatışmaların ortasında kaldı. Ayrıca bu dönemde şehirde Şiîlik revaç bulmaya başladı. IX. yüzyılın sonlarında Halife Mu'tazıd, oğlu Muktefî Ali'ye Rey ve diğer şehirlerin idaresini verdi ve Muktefî, Rey'de oturmaya başladı (281/894-5). Ancak bu asırda Mâverâünnehir ve Horasan'da kurulan Sâmânîler Devleti, bu yüzyılın sonlarından itibaren Rey'e müdahale etmeye başladılar ve şehri ele geçirdiler

71 Taberî, Tarih-i Taberî (Tarihü'l-Rusul ve'l-Mülûk), X, 63; İbnü'l-Esîr, el-Kâmil fi't-Tarih, VII, 404.

72 Gerdîzî, Ebî Said Abdülhayy b. el-Dahhâk b. Mahmûd, Zeynü'l-Ahbâr, Tashih Abdülhayy Habîbî (Tahran: Donyâ-yi Ketâb, 1363), 323; İbn Haldûn, Tarihu İbn Haldûn (el-İber), III, 442; Taberî, Tarih-i Taberî(Tarihü'l-Rusul ve'l-Mülûk), X, 93; İbnü'lEsîr, el-Kâmil fi't-Tarih, VII, 430-31.

73 İbn Hurdâzbih, Ebû'l-Kasım Ubeydullah bin Abdullah, el-Mesâlikü’l-Memâlik, Çeviren Murat Ağarı, (İstanbul, 2008), 35; Ya’kûbî, Ülkeler Kitabı, 57. 
(289/902).

\section{Kaynaklar}

Aybek ed-Devâdarî, Ebî Bekr bin Abdullah. Kenzü'd-Dürer ve Câmiü'l-Gurer. Tahkik Dorotia Krafolski. C. V. Kahire, 1391.

Belâzûrî, Ahmed b. Yahyâ. Fütûhu'l-Büldân. Beyrut: Dâr ve Mektebü'l-Hilâl, 1988; Türkçe trc. Fütûhu'l-Büldân (Ülkelerin Fetihleri). Çeviren Mustafa Fayda. İstanbul: Siyer Yayınları, 2013.

Bozkurt, Nahide. "Hâdî-İlelhak". Dİ, XV, (1997), 16-17.

—. "Nasr b. Seyyâr". DIA, XXXII, (2006), 415-16.

Ca'feriyân, Resûl. Tarih-i Gostereş-i Teşeyyu der Rey. Tahran: Âsitân-i Mukaddes-i Hazret-i Abdülazîm, 1371.

Darmesteter, James. The Zend-Avesta, Vendidad. Oxford: Clarendon Press, 1880.

Diakonoff, İgor M. Tarih-i Mâd. Çeviren Kerîm Keşâverz. Tahran: Bongâh-i Tercüme ve Neşr-i Kitâb, 1345.

Ebû'l-Fidâ, el-Melikü'l-Müeyyed İmâdüddîn İsmâîl b. Alî. el-Muhtasar fi Ahbârü'l-Beşer. C. II. Kahire, 1325.

Dineverî, Ebû Hanîfe. el-Ahbâru't-Tıvâl. Tahkîk Abdülmün'im Âmir. Kahire: Dâru İhyâ-i elKütübü'l-Arabî, 1960.

Ferşçiyan, Rıza. Pîşgâmân-i Teşeyyu der İran. Kum: İntişârât-1 Zâir, 1384.

Gerdîzî, Ebî Said Abdülhayy b. el-Dahhâk b. Mahmûd. Zeynü'l-Ahbâr. Tashih Abdülhayy Habîbî. Tahran: Donyâ-yi Ketâb, 1363.

Halife b. Hayyât. Tarihu Halife b. Hayyât. Tahkik Ekrem Ziyâ El-Ömerî. Riyad: Dâru Tîbe, 1985. Hamdullah Müstevfî. Nüzhetu'l-Kulûb. Nşr. Guy Le Strange. London-Leiden, 1915.

Hamdullah Müstevfî Kazvînî. Tarih-i Güzîde. Tashih Abdulhüseyin Nevâî. 3. baskı. Tahran: Emîr Kebîr, 1364.

I'timâdü's-Saltana, Muhammed Hasan Hân. Tarih-i Muntazam-i Nâsırî. C. I. Tahran: Donyâ-yi Ketâb, 1367.

İbn Fakîh, Ahmed b. Muhammed. Kitâbü'l-Büldân. Tahkik Yusuf El-Hâdî. Beyrut: Âlemü'l-Kütüb, 1416.

İbn Haldûn, Abdurrahman b. Muhammed. Tarihu İbn Haldûn (el-ïber). Tahkik Halil Şehâde ve Süheyl Zekkâr. C. III. Beyrut: Dârü'l-Fikr, 1421.

İbn Hurdâzbih, Ebû'l-Kasım Ubeydullah bin Abdullah. el-Mesâlikü'l-Memâlik. Çeviren Murat Ağarı. İstanbul, 2008.

İbn Kesîr, Ebû'l-Fidâ İmâdüddîn İsmâil bin Şihâbüddîn Ömer. el-Bidâye ve 'n-Nihaye (Büyük İslam Tarihi). Çeviren Mehmet Keskin. C. X, XI. İstanbul: Çağrı Yay., 1994.

İbn Miskeveyh, Ebû Ali Ahmed b. Muhammed. Tecâribü'l-Ümem. Tahkik Ebû'l-Kâsım İmâmî. C. III, IV. Tahran: Suroş, 1379.

İbn Tağrîbirdî, Cemâleddîn Ebû'l-Mehâsin. en-Nücĥmu'z-Zâhire fî Mülûk-i Mısr ve 'l-Kâhire. C. I, II. Misır: Vezâretü's-Sekâfe ve'l-İrşâdü'l-Kavmî, y.y.

İbnü'l-Cevzî, Cemâleddîn Ebû'l-Ferec Abdurrahmen b. Ali b. Muhammed. el-Muntazam fi Târîhi'lÜmem ve'l-Mülûk. Tahkik Muhammed Abdülkadir Atâ ve Mustafa Abdülkadir Atâ. C. VIII, IX. Beyrut: Darü'l-Kütübü'l-İlmiyye, 1412.

İbnü'l-Esîr, Ebü'l-Hasen İzzüddîn Alî b. Muhammed b. Muhammed eş-Şeybânî el-Cezerî. elKâmil fi t't-Tarih. Çeviren C. III, VII. Ahmet Ağırakça; C. IV. M. Beşir Eryarsoy; C. V. Yunus Apaydın; C. VI. Abdullah Köşe. İstanbul: Bahar Yayınları, 1991.

İbnü'l-Verdî, Zeyneddîn Ömer b. Muzaffer b. Ebî'l-Fevâris. Tarihu İbnü'l-Verdî. C. I. Beyrut: Daru'l-Kutubu'l-İlmiyye, 1417. 
İsfahânî, Hamza b. Hasan. Tarih-i Peyâmberân ve Şâhân. Çeviren Cafer Şiâr. Tahran: İntişârât-1 Bonyâd-1 Ferheng-i İran, 1346.

Kerîmân, Hüseyin. Rey-i Bâstân. C. I. Tahran: Silsile-i İntişârât-i Encümen-i Âsâr-i Millî, 1345; C. II. Tahran: Silsile-i İntişârât-i Encümen-i Âsâr-i Millî, 1349.

Kudâme b. Ca'fer, Kudâme b. Ziyâd el-Kâtib el-Bağdâdî. Kitâbü'l-Harâc ve Sinâ'ati'l-Kitâbe. Tahkik Muhammed Hüseyin Zebîdî. Bağdad: Dârü’l-Reşîdü’n-Neşr, 1981.

Kurt, Hasan. "Tâhir b. Hüseyin". DİA, XXXIX, (2010), 399-400.

—. "Tâhirîler". DIA, XXXIX, (2010), 403-4.

Mahmûdpûr, Muhammed, ve Muhammed Hüseyin Muhammedî. "Rey". Dâneşnâme-i Cihân-i Íslâm, C. XXI. Tahran, 1395.

Makdisî, Muhammed b. Ahmed. Ahsenü't-Tekâsîm fî Marifetü'l-Ekâlîm. Leiden: Brill, 1906.

Mesûdî, Ebî'l-Hasan Ali b. el-Hüseyin b. Ali. Mürûcü'z-Zeheb ve Meâ'dini'l-Cevher. Tahkîk Esed Dâğer. C. III, IV. Kum: Dârü'l-Hicre, 1409.

Miles, George Carpenter. The Numismatic History of Rayy. C. II. American Numismatic Society, 1938.

Minorsky, V. "Rey”. IA, IX, (1964), 721-24.

Minorsky, V., ve [C. E. Bosworth]. "al-Rayy". EI², VIII, (1995), 471-73.

Mücmelü't-Tevârîh ve'l-Kısas. Tashih Melikü'ş-Şuerâ Behâr, Tahran: Kelâle-i Hâver, y.y.

Özaydın, Abdülkerim. "Muvaffak el-Abbâsî”. DİA, EK-2, (2016), 332-34.

Özgüdenli, Osman G. "Rey”. DIA, XXXV, (2008), 40-41.

Pîrniyâ, Hasan. Tarih-i İran-i Bâstân. C. III. Tahran: Donyâ-yı Ketâb, 1375.

Rante, Rocco. Rayy: From Its Origins to the Mongol Invasion: an Archaeological and Historiographical Study. Brill, 2014.

Şebânkârâi, Muhammed bin Ali bin Muhammed. Mecma 'u'l-Ensab. Tashih Mir Haşim Muhaddis. C. I. Tahran, 1381.

Sem ‘ânî, Abdülkerim b. Muhammed b. Mansûr. el-Ensâb. C. XIII. Haydarabâd: Meclis-i Dâiretü’lMuarrifü'l-Osmaniyye, 1382.

Sibt İbnü'l Cevzî, Şemseddin Ebu'l-Muzaffer Yusuf b. Kızoğlu. Mirâtü'z-Zaman fî Tarihi'l-Âyân. Tahkik İbrahim Ez-Zeybek. C. XII, XIII, XVI. Dımaşk: Dârü'l-Risâletü'l-Âlemiyye, 1434.

Strange, Guy Le. The Lands of the Eastern Caliphate: Mesopotamia, Persia, and Central Asia from the Moslem conquest to the time of Timur. Cambridge, 1930.

Suyûtî, Celâleddîn Abdurrahman. Tarihü'l-Hulefâ. Tahkik Hamdî El-Demirdâş. Mekke: Mektebe-i Nizâru Mustafa Elbâz, 1425.

Taberî, Ebû Ca'fer Muhammed b. Cerîr. Tarih-i Taberî (Tarihü'l-Rusul ve'l-Mülûk). Tahkîk Muhammed Ebûlfazl İbrahim. C. VI, VII, VIII, IX, X. Beyrut: Dâru't-Turâs, 1387.

Ya'kûbî, Ahmed b. İshâk. Kitâbü'l-Büldân. Tahkik Muhammed Emin Zanâvî. Beyrut: Daru'lKutubu'l-İlmiyye, 1422; Türkçe trc. Ülkeler Kitabı. Çeviren Murat Ăgarı. İstanbul, 2002.

—. Tarihü'l-Ya'kûbî. C. II. Beyrut: Dâru Sâdr, y.y.

Yâkût el-Hamevî, Şihâbeddin Yakut b. Abdullah el-Rûmî. Mu'cemü'l-Büldân. C. III, IV, V. Beyrut: Dâru Sâdr, 1995.

—. Müşterek-i Yâkût Hamevî. Çeviren Muhammed Pervîn Gonâbâdî. Tahran: Emîr Kebîr, 1362.

Zehebî, Șemseddîn Muhammed bin Ahmed bin Osman. Tarihü'l-İslâm ve Vefâyat el-Meşâhîr ve'lÂlâm. Editör Tahkik Ömer Abdusselâm Tedmürî. C. VIII, IX, XIII, XIX. Beyrut: Dâru'lKitabu'l-Arabî, 1413.

Zekeriyyâ Kazvînî, Zekeriyyâ b. Muhammed. Asârü'l-Bilâd ve Ahbârü'l-İbâd. Beyrut: Dâru Sâdr, 1998. 